Barker, P.F., Camerlenghi, A., Acton, G.D., and Ramsay, A.T.S. (Eds.)

Proceedings of the Ocean Drilling Program, Scientific Results Volume 178

\title{
20. DATA REPORT: OXYGEN AND CARBON ISOTOPE MEASUREMENTS ON NEOGLOBOQUADRINA PACHYDERMA (S) FROM HOLES 1096B AND 1101A, Antarctic Peninsula Margin, LEG 178'
}

Peter F. Barker, ${ }^{2}$ Lisa E. Osterman, ${ }^{3}$ and Michael A. Hall ${ }^{4}$

\begin{abstract}
Oxygen and carbon isotopic ratios were measured on left-coiling Neogloboquadrina pachyderma separated from sediments recovered from Holes 1096B (3152 m water depth) and 1101A (3280 m water depth) during Ocean Drilling Program Leg 178. The sediment samples were widely spaced, extending over the past $2.1 \mathrm{~m}$.y. The nature of the sediments from which they were separated and the measured oxygen isotopic ratios show that $N$. pachyderma (s) is preserved in both glacial and interglacial sediments over the entire period, pointing to the possibility of extracting a detailed isotopic record at these sites extending back to $2.1 \mathrm{Ma}$.
\end{abstract}

\section{INTRODUCTION}

During Ocean Drilling Program (ODP) Leg 178, three sites were drilled on two of eight or nine fine-grained sediment drifts on the upper continental rise off the Pacific margin of the Antarctic Peninsula (Barker, Camerlenghi, Acton, et al., 1999; Barker et al., in press). The main aim was to recover a continuous, high-resolution record of the state of glaciation of the adjacent continent. The drifts experienced
${ }^{1}$ Barker, P.F., Osterman, L.E., and Hall, M.A., 2001. Data report: Oxygen and carbon isotope measurements on Neogloboquadrina pachyderma (s) from Holes 1096B and 1101A, Antarctic Peninsula margin, Leg 178. In Barker, P.F., Camerlenghi, A., Acton, G.D., and Ramsay, A.T.S. (Eds.), Proc. ODP, Sci. Results, 178, 1-10 [Online]. Available from World Wide Web: <http://www-odp.tamu.edu/ publications/178_SR/VOLUME/ CHAPTERS/SR178_20.PDF>. [Cited YYYY-MM-DD]

${ }^{2}$ British Antarctic Survey, Madingley Road, Cambridge CB3 OET, United Kingdom. p.barker@bas.ac.uk ${ }^{3}$ U.S. Geological Survey, MS 926A, Reston VA 20192, USA.

${ }^{4}$ The Godwin Laboratory, Cambridge University, New Museums Site, Cambridge CB2 3SA, United Kingdom.

Initial receipt: 1 September 2000 Acceptance: 26 June 2001

Web publication: 13 November 2001

Ms 178SR-220 
mainly pelagic deposition during interglacials, comprising biogenic debris, ice-rafted detritus, and possibly other minor terrigenous material, usually bioturbated. During glacial periods, when an ice sheet was grounded to the continental shelf edge and depositing unsorted sediment on the upper continental slope, drift deposition was mainly of barren, laminated (i.e., unbioturbated) clays from the suspended finegrained component of turbidity currents originating in the unstable part of upper slope deposits (with some fine silts, also of turbidity-current origin). The alternation of thicker laminated and thinner bioturbated, mainly fine-grained terrigenous deposits extended to the base of the deepest hole at the shallower, more proximal sites (Sites 1096 and 1101) and to $9 \mathrm{Ma}$ at Site 1095. The preservation of cyclicity within the drifts suggested that the residence time on the upper slope of the unstable component of glacially transported material was short compared with the length of a glacial cycle.

Biogenic debris recovered from the drifts was largely diatomaceous, but biogenic carbonate (mainly Neogloboquadrina pachyderma [s] and nannofossils) was found at intervals in the younger drift sediments at shallower sites and was most abundant within the period from 0.8 to 2.1 Ma at Sites 1096 and 1101. Biogenic carbonate seemed to occur mainly in narrow intervals of bioturbated sediment, a few of which could be defined as foraminiferal ooze. Calcareous benthic foraminifers and other planktonic species were sparse, but again were most abundant in these narrow intervals. In sediments older than $2.1 \mathrm{Ma}$, calcareous tests were not preserved, possibly as a consequence of a higher biosiliceous productivity.

\section{METHODS}

For this preliminary study a $20-\mathrm{cm}^{3}$ sample was collected from every core section, plus (larger) core catcher samples, with an additional subsequent $20-\mathrm{cm}^{3}$ sample from sections where foraminifers were identified by the sedimentological description. The wet samples were processed aboard ship.The samples were soaked in distilled water and agitated for an hour to assist in disaggregation then were wet-sieved at $63 \mu \mathrm{m}$. The washed residue was dried under a heat lamp, and the temperature was monitored so as not to exceed $50^{\circ} \mathrm{C}$. Samples were dry sieved at $150 \mu \mathrm{m}$, and all planktonic foraminifers were picked from the sample. In foraminifer-rich samples, a maximum of 50 foraminifers was picked. All samples measured were the quadrate form of N. pachyderma (s) (the "encrusted" form of Kohfeld et al., 1996).

For isotopic analysis (at the Godwin Laboratory, University Cambridge, United Kingdom), the foraminifer samples were picked into glass vials, crushed, and soaked in a $3 \%$ solution of hydrogen peroxide for $30 \mathrm{~min}$. Acetone was added, the sample was ultrasonicated for $30 \mathrm{~s}$, and the liquid was carefully decanted using a tissue. The samples were then dried in an oven at $50^{\circ} \mathrm{C}$ overnight. The smaller samples (" $\mathrm{M}$ " in the tables) were transferred to larger glass vials that were sealed with a septa and cap and analyzed using a Micromass Multicarb sample preparation system attached to a PRISM mass spectrometer. The larger samples ("S") were transferred to smaller glass containers and analyzed using a Micromass Autocarb common acid bath system attached to a SIRA mass spectrometer. A series of calibration and check carbonates were analyzed with every batch of samples. Results are reported with reference to the international standard Vienna Peedee belemnite 
(VPDB), and the precision is better than $\pm 0.06 \mathrm{ppm}$ for $\delta^{13} \mathrm{C}$ and \pm 0.08 ppm for $\delta^{18} \mathrm{O}$.

Measurements from both sites are listed in Tables T1 and T2 and displayed against depth in Figure F1. Ages were attributed to samples assuming uniform sedimentation rates between shipboard-identified magnetic reversals.

\section{DISCUSSION}

Kohfeld et al. (1996) showed that oxygen isotopic ratios for N. pachyderma (s) are a useful proxy for water chemistry and temperature south of the Polar Front and suggested that the oxygen isotopic composition of encrusted forms reflects close to an average temperature of water above the pycnocline. At present, close to the drifts (figure F6 of Barker and Camerlenghi, 1999), the pycnocline is shallow and the average temperature above it is low $\left(\sim-0.5^{\circ} \mathrm{C}\right)$. Late Pleistocene glacial average temperatures can have been little different. Grobe et al. (1990) presented data from N. pachyderma (s) from the eastern Weddell Sea margin that showed a correlation between carbon and oxygen isotopic variations through late Pleistocene glacial cycles, which the data reported here can examine.

The samples from Leg 178 are widely distributed and do not provide a detailed description of any single glacial cycle at either site (Fig. F1). However, they come from both laminated and bioturbated sediments, taken to represent both glacial and interglacial states, according to the assumed model of sedimentation on the drifts. This is borne out by the measured oxygen isotopic ratios. The high values, approaching 5.0 ppm, which are abundant at both sites (dominant at Site 1096) after 800-1000 ka, are difficult to reconcile with anything other than a low surface water temperature and large global ice volume. They come mainly from laminated sediments. Before 800-1000 ka, measured oxygen isotopic ratios are lower, reflecting perhaps smaller ice volumes and "interglacial" surface water conditions. Many more of these samples come from bioturbated sediments. In Figure F2, the oxygen isotopic values from both sites are plotted against the background of the detailed curve from benthic foraminifers at ODP Site 659 (Tiedemann et al., 1994). Precise correlation in timing is not intended by this comparison because of uncertainties in the estimated ages of the Leg 178 data (i.e., in the assumption of uniform sedimentation rates between magnetic reversals). However, it is clear from Figure F2 that the N. pachyderma (s) values reported here lie within the range of plausible isotopic variation (because low-latitude deep and bottom water is taken to have an origin in, and largely to retain the low temperatures and other properties of, high-latitude surface water) and reflect both glacial and interglacial conditions. Diagenesis could of course make such general coincidence merely fortuitous. Grobe et al. (1990) detect diagenesis (under reducing conditions) in samples from very shallow depths on the continental slope off Queen Maud Land. That diagenesis, however, leads to higher oxygen isotopic ratios. In Figure F2, the isotopic values decrease back in time, following the low-latitude curve, and low values occur at intervals throughout, so that tight limits are placed on the extent of any such diagenetic modification at Sites 1096 and 1101, and the general coincidence remains meaningful.

Figure F3 is a crossplot of carbon against oxygen isotopic ratios, which does not show the clear correlation between the two that was
T1. Oxygen and carbon isotopic measurements, Hole 1096B, p. 9.

T2. Oxygen and carbon isotopic measurements, Hole 1101A, p. 10.

F1. Oxygen and carbon isotopic ratios vs. depth, p. 6 .

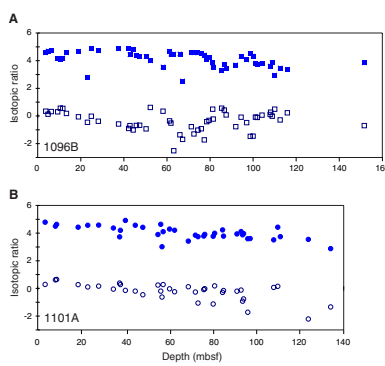

F2. Oxygen isotopic ratios compared with benthic foraminifers, p. 7.

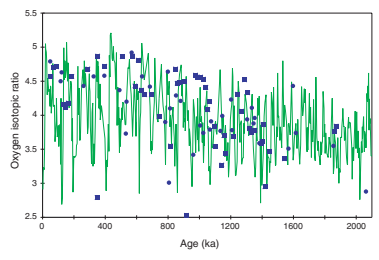

F3. Carbon vs. oxygen isotopic ratios, p. 8.

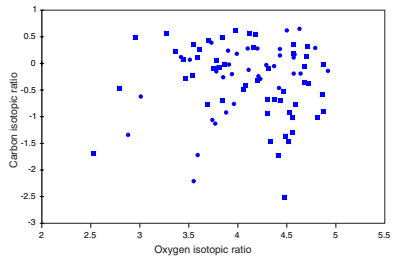


found by Grobe et al. (1990). Nevertheless, the range of carbon isotopic values in the Leg 178 data (leaving aside the three probably discrepant values, one from the lower part of Hole 1096B and two from the lower part of Hole 1101A, listed in Tables T1 and T2) is at least as great as that of the data reported by Grobe et al. (1990). It is clear that the existing data do not provide an opportunity for examining the level and significance of carbon isotopic variation south of the Polar Front through glacial cycles (e.g. Kohfeld et al., 2000), but a more detailed sample set from these sites would present this possibility.

Little can be said here about the abundance of $N$. pachyderma (s). Donner and Wefer (1994) in the Antarctic and Kohfeld et al. (1996) in the Arctic suggest that N. pachyderma (s) flux to the seabed is critically dependent on ice cover, even within polynyas. The relevance of the persistence of $N$. pachyderma (s) presence in the Leg 178 holes to a history of ice cover in this area during late Pleistocene glacial periods is uncertain, but that persistence seems likely to allow continuous sampling (particularly if only a small number of specimens would be required for each measurement).

\section{CONCLUSIONS}

Oxygen and carbon isotopic ratios of N. pachyderma (s) from Pleistocene and latest Pliocene sediments from Holes 1096B and 1101A appear to be primary, representing the isotopic composition of the shallow Antarctic water mass. They are widely spaced in time, so do not provide a detailed description of variation through any glacial cycle, but do represent both glacial and interglacial conditions, and therefore point to the potential for detailed sampling and analysis at these sites. The measured samples are more numerous back to 1.6 Ma, but shipboard observations of carbonate preservation suggest that such potential extends back to 2.1 Ma.

\section{ACKNOWLEDGMENTS}

This research used samples and/or data provided by the Ocean Drilling Program (ODP). ODP is sponsored by the U.S. National Science Foundation (NSF) and participating countries under management of Joint Oceanographic Institutions (JOI), Inc.

Hannes Grobe and Rainer Zahn provided useful comments on the manuscript. 


\section{REFERENCES}

Barker, P.F., Camerlenghi, A., Acton, G.D., et al., 1999. Proc. ODP, Init. Repts., 178 [CDROM] . Available from: Ocean Drilling Program, Texas A\&M University, College Station, TX 77845-9547, U.S.A.

Barker, P.F., and Camerlenghi, A., 1999. An approach to Antarctic glacial history: the aims of Leg 178. In Barker, P.F., Camerlenghi, A., Acton, G.D., et al., 1999. Proc. ODP, Init. Repts., 178, 1-44 [CD-ROM]. Available from: Ocean Drilling Program, College Station, TX 77845-9547, U.S.A.

Barker, P.F., Camerlenghi, A., and Shipboard Scientific Party, in press. Antarctic glacial history, step 1: the continental margin drilled by ODP Leg 178. Proc. $8^{\text {th }}$ Internat. Symp. on Antarct. Earth Sci.: Wellington, New Zealand.

Donner, B., and Wefer, G., 1994. Flux and stable isotope composition of Neogloboquadrina pachyderma and other planktonic foraminifers in the Southern Ocean (Atlantic sector). Deep-Sea Res., 41:1733-1743.

Grobe, H., Mackensen, A., Hubberten, H.-W., Spiess, V., and Fütterer, D.K., 1990. Stable isotope record and late Quaternary sedimentation rates at the Antarctic continental margin. In Bleil, U., and Thiede, J. (Eds.), Geological History of Polar Oceans: Arctic versus Antarctic. NATO/ASI Series C., Dordrecht (Kluwer Academic Publishers), 539-571.

Kohfeld, K.E., Anderson, R.F., and Lynch-Stieglitz, J., 2000. Carbon isotopic disequilibrium in polar planktonic Foraminifera and its impact on modern and Last Glacial Maximum reconstructions. Paleoceanography, 15:53-64.

Kohfeld, K.E., Fairbanks, R.G., Smith, S.L., and Walsh, I.D., 1996. Neogloboquadrina pachyderma (sinistral coiling) as paleoceanographic tracers in polar oceans: evidence from Northeast Water Polynya plankton tows, sediment traps, and surface sediments. Paleoceanography, 11:679-699.

Tiedemann, R., Sarnthein, M., and Shackleton, N.J., 1994. Astronomic timescale for the Pliocene Atlantic $\delta^{18} \mathrm{O}$ and dust flux records of Ocean Drilling Program Site 659. Paleoceanography, 9:619-638. 
P.F. BARKER ET AL.

DATA REPORT: OXYGEN AND CARBon ISOTOPE MEASUREMENTS

Figure F1. Oxygen (solid symbols) and carbon (open symbols) isotopic ratios from Tables T1, p. 9, and T2, p. 10, plotted against depth in (A) Hole 1096B (squares) and (B) Hole 1101A (circles).

A

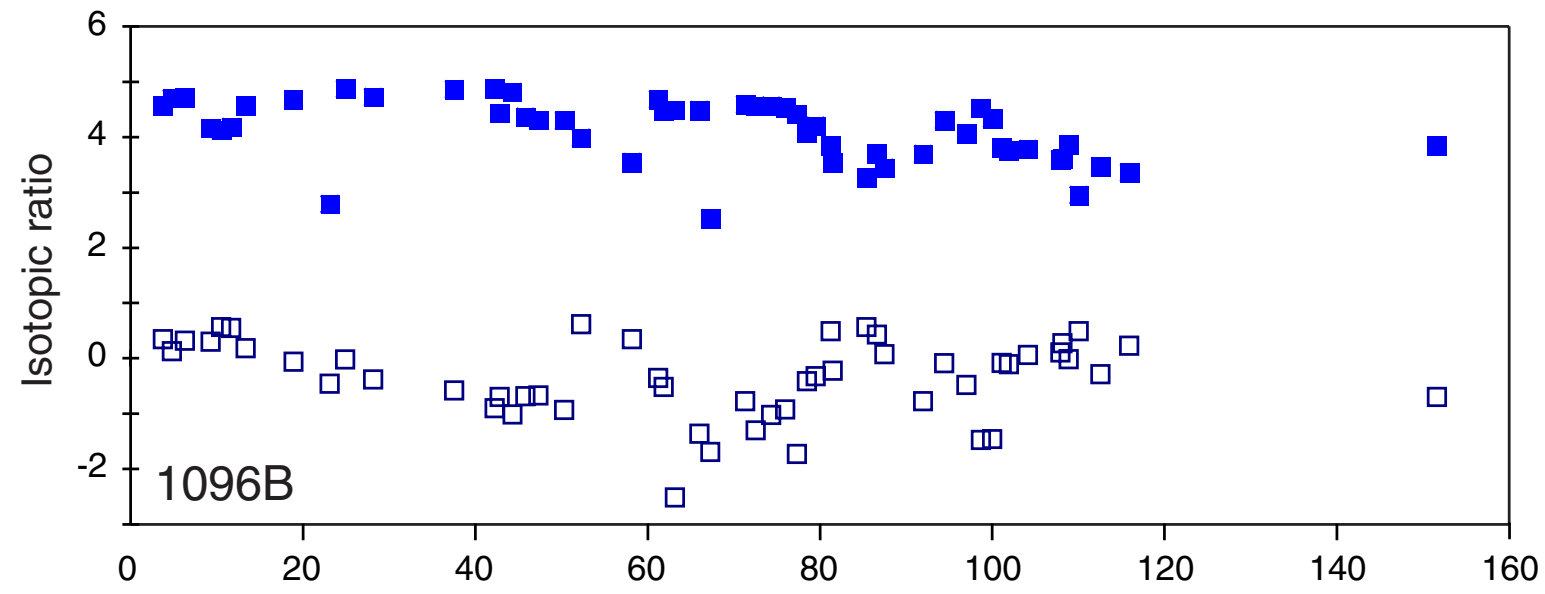

B

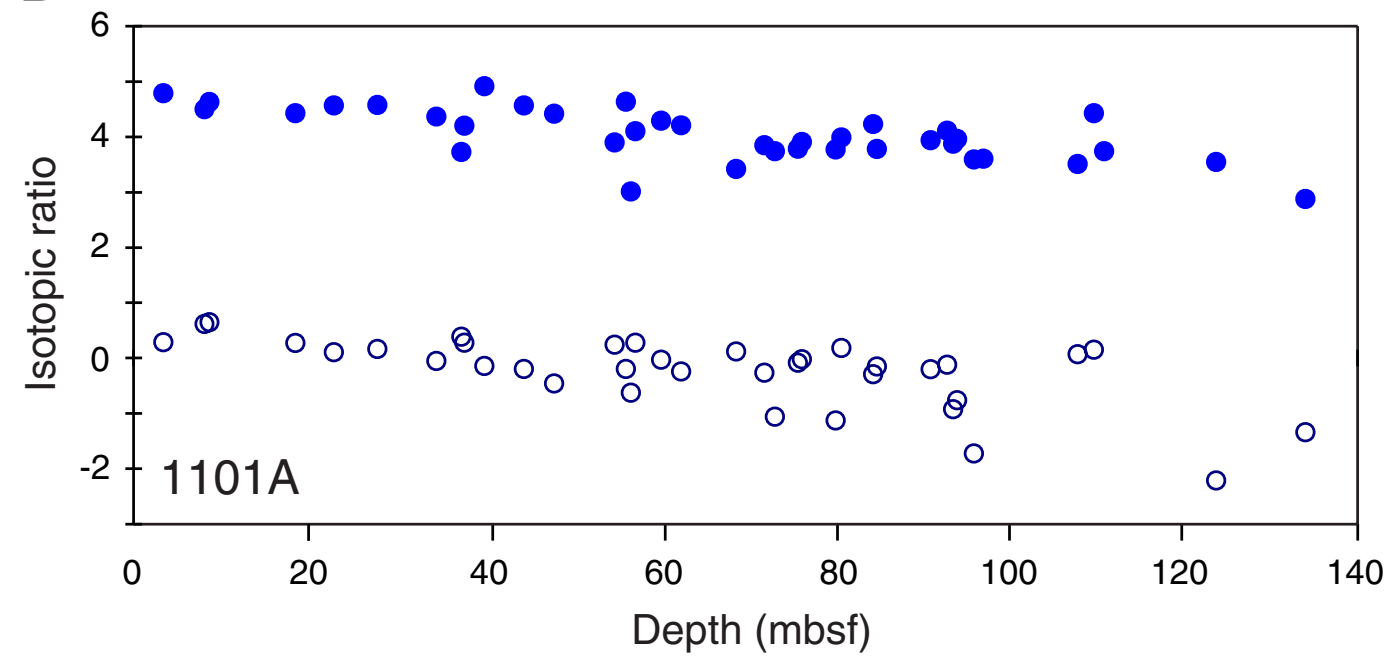


P.F. BARKER ET AL.

DATA REPORT: OXYGEN AND CARBon ISOTOPE MEASUREMENTS

Figure F2. Oxygen isotopic ratios from Holes 1096B (squares) and 1101A (circles) compared with detailed measurements (green) on benthic foraminifers at ODP Site 659 (Tiedemann et al., 1994). There is general coincidence between the detailed curve and the range of values measured at Sites 1096 and 1101. Exact correlation is not intended.

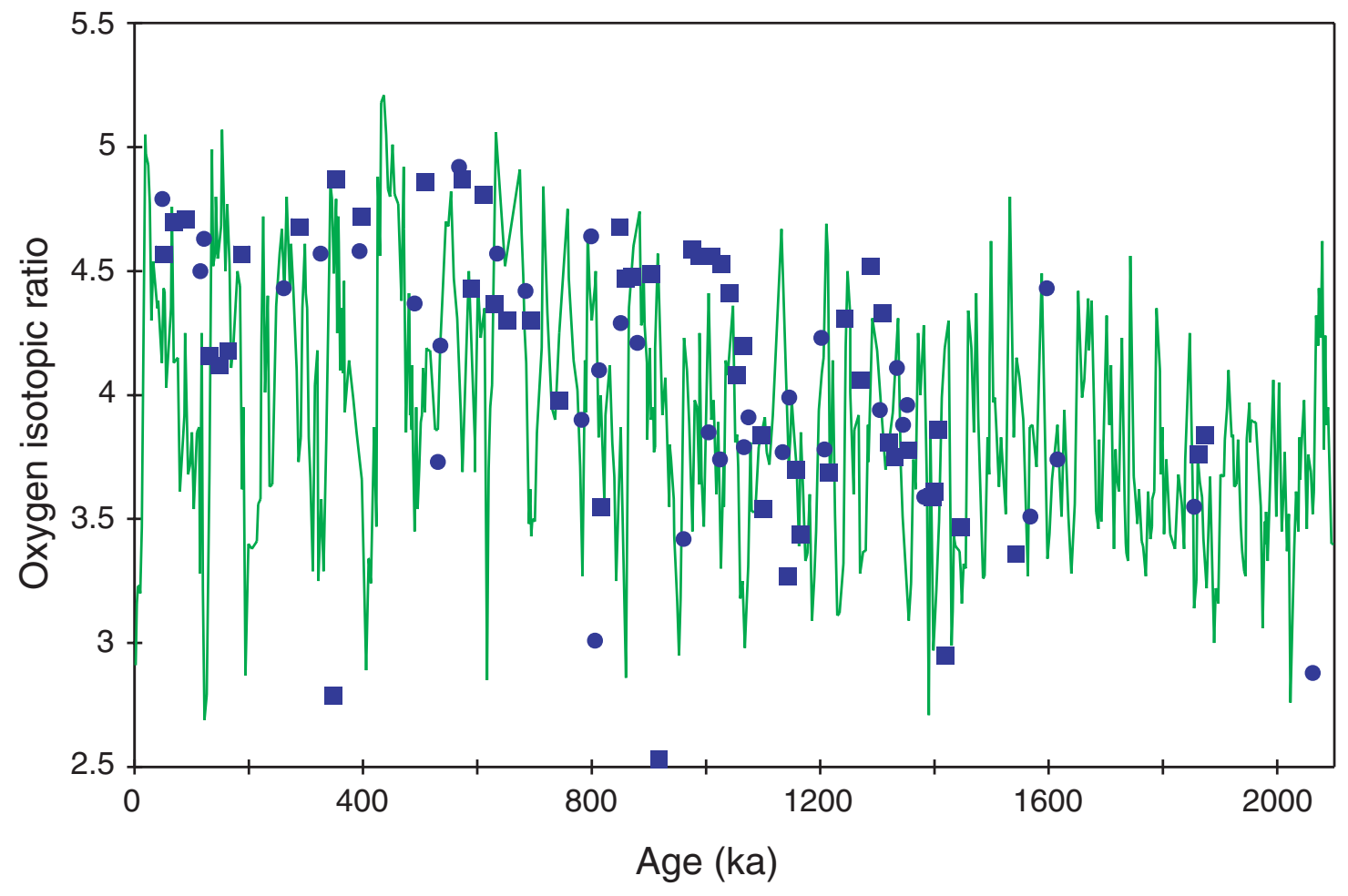


P.F. BARKER ET AL.

DATA REPORT: OXYGEN AND CARBON ISOTOPE MEASUREMENTS

Figure F3. Carbon vs. oxygen isotopic ratios from Holes 1096B (squares) and 1101A (circles). A strong correlation between the two parameters through glacial cycles (as noted by Grobe et al., 1990) is not seen.

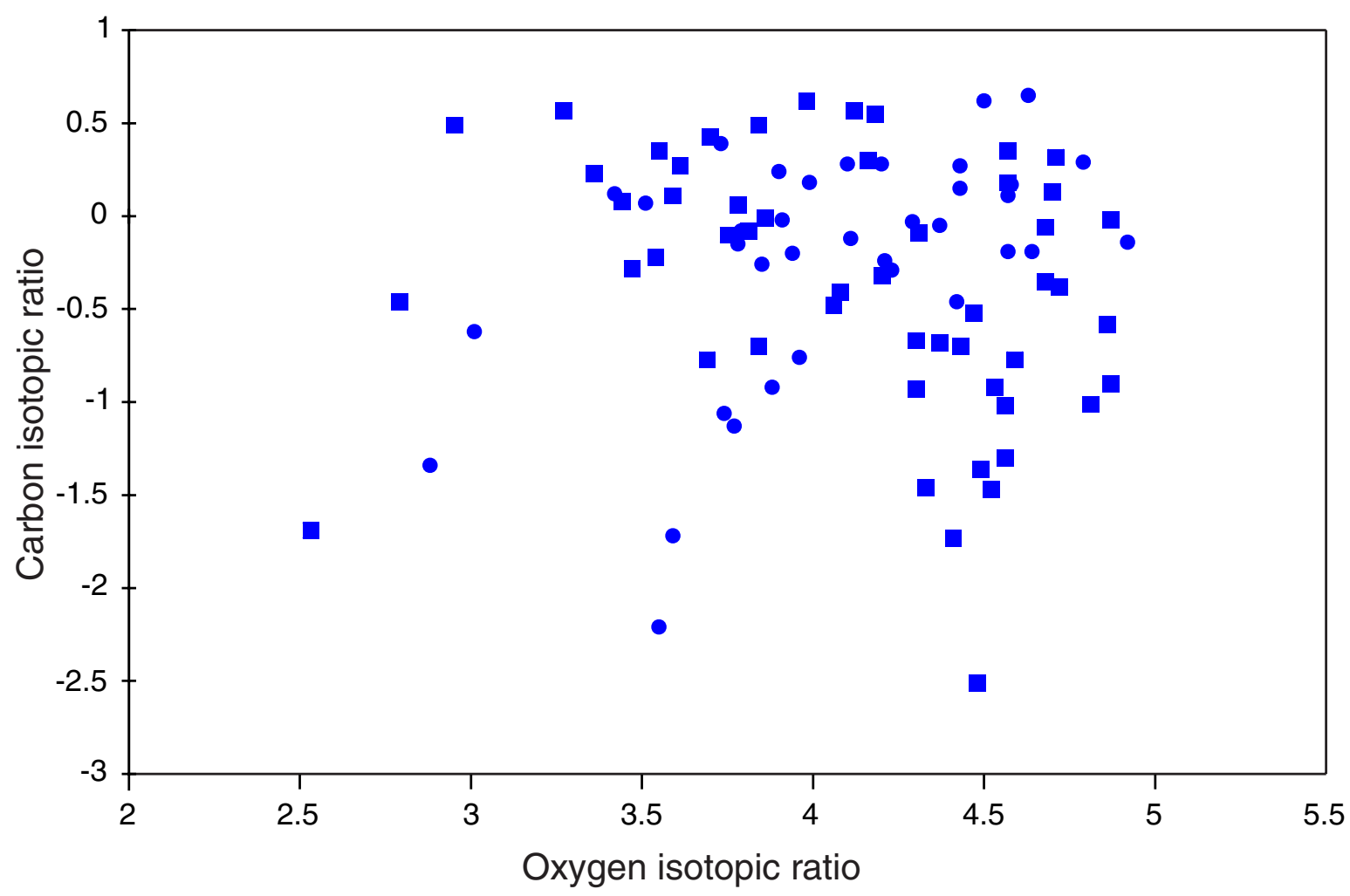


P.F. BARKER ET AL.

DATA REPORT: OXYGEN AND CARBON ISOTOPE MEASUREMENTS

Table T1. Oxygen and carbon isotopic measurements on N. pachyderma (s), Hole 1096B.

\begin{tabular}{|c|c|c|c|c|c|}
\hline $\begin{array}{l}\text { Core, section, } \\
\text { interval }(\mathrm{cm})\end{array}$ & $\begin{array}{l}\text { Depth } \\
\text { (mbsf) }\end{array}$ & $\begin{array}{l}\text { Age } \\
(\mathrm{ka})\end{array}$ & $\begin{array}{l}\delta^{18} \mathrm{O} \\
(\% o)\end{array}$ & $\begin{array}{l}\delta^{13} \mathrm{C} \\
(\% o)\end{array}$ & Analysis \\
\hline \multicolumn{6}{|l|}{ 178-1096B- } \\
\hline $1 \mathrm{H}-\mathrm{CC}, 7$ & 3.7 & 51.46 & 4.57 & 0.35 & $\mathrm{M}$ \\
\hline $2 \mathrm{H}-1,100$ & 4.8 & 68.43 & 4.7 & 0.13 & $M$ \\
\hline $2 \mathrm{H}-2,100$ & 6.3 & 89.29 & 4.71 & 0.32 & $\mathrm{~S}$ \\
\hline $2 \mathrm{H}-4,100$ & 9.3 & 131.02 & 4.16 & 0.3 & $M$ \\
\hline $2 \mathrm{H}-5,70$ & 10.5 & 147.71 & 4.12 & 0.57 & $\mathrm{M}$ \\
\hline $2 \mathrm{H}-6,40$ & 11.64 & 163.57 & 4.18 & 0.55 & $S$ \\
\hline $2 \mathrm{H}-\mathrm{CC}, 18$ & 13.32 & 186.93 & 4.57 & 0.18 & $S$ \\
\hline $3 \mathrm{H}-4,109$ & 18.89 & 288.88 & 4.68 & -0.06 & $M$ \\
\hline $3 \mathrm{H}-\mathrm{CC}, 11$ & 23.11 & 347.48 & 2.79 & -0.46 & $M$ \\
\hline $4 \mathrm{H}-2,59$ & 24.89 & 351.47 & 4.87 & -0.02 & $S$ \\
\hline $4 \mathrm{H}-5,69$ & 28.14 & 396.67 & 4.72 & -0.38 & $M$ \\
\hline $5 \mathrm{H}-4,76$ & 37.56 & 507.81 & 4.86 & -0.58 & $S$ \\
\hline $5 \mathrm{H}-\mathrm{CC}, 29$ & 42.25 & 573.04 & 4.87 & -0.9 & $S$ \\
\hline $6 \mathrm{H}-1,100$ & 42.8 & 588.76 & 4.43 & -0.7 & $M$ \\
\hline $6 \mathrm{H}-2,99$ & 44.29 & 609.48 & 4.81 & -1.01 & $S$ \\
\hline $6 \mathrm{H}-3,99$ & 45.79 & 629.79 & 4.37 & -0.68 & $M$ \\
\hline $6 \mathrm{H}-4,100$ & 47.3 & 651.35 & 4.3 & -0.67 & $S$ \\
\hline $6 \mathrm{H}-6,100$ & 50.3 & 693.07 & 4.3 & -0.93 & $M$ \\
\hline $7 \mathrm{H}-1,100$ & 52.3 & 742.86 & 3.98 & 0.62 & $M$ \\
\hline 7H-5, 100 & 58.2 & 815.35 & 3.55 & 0.35 & $\mathrm{M}$ \\
\hline 7H-CC, 28 & 61.22 & 848.4 & 4.68 & -0.35 & $S$ \\
\hline $8 \mathrm{H}-1,104$ & 61.84 & 857.81 & 4.47 & -0.52 & $S$ \\
\hline $8 \mathrm{H}-2,85$ & 63.15 & 870.5 & 4.48 & -2.51 & $M$ \\
\hline $8 \mathrm{H}-4,70$ & 66 & 903.34 & 4.49 & -1.36 & $M$ \\
\hline $8 \mathrm{H}-5,46$ & 67.26 & 917.12 & 2.53 & -1.69 & $\mathrm{M}$ \\
\hline $9 \mathrm{H}-1,104$ & 71.34 & 975.56 & 4.59 & -0.77 & $S$ \\
\hline $9 \mathrm{H}-2,72$ & 72.52 & 988.48 & 4.56 & -1.3 & $S$ \\
\hline $9 \mathrm{H}-3,100$ & 74.3 & 1007.96 & 4.56 & -1.02 & $S$ \\
\hline $9 \mathrm{H}-4,115$ & 75.95 & 1026.01 & 4.53 & -0.92 & $S$ \\
\hline $9 \mathrm{H}-5,103$ & 77.33 & 1041.12 & 4.41 & -1.73 & $S$ \\
\hline $9 \mathrm{H}-6,69$ & 78.49 & 1053.81 & 4.08 & -0.41 & $S$ \\
\hline $9 \mathrm{H}-7,17$ & 79.47 & 1064.54 & 4.2 & -0.32 & $\mathrm{M}$ \\
\hline $10 \mathrm{H}-1,142$ & 81.22 & 1097.26 & 3.84 & 0.49 & $S$ \\
\hline $10 \mathrm{H}-2,15$ & 81.45 & 1099.77 & 3.54 & -0.22 & $M$ \\
\hline $10 \mathrm{H}-4,107$ & 85.37 & 1142.67 & 3.27 & 0.57 & $S$ \\
\hline $10 \mathrm{H}-5,81$ & 86.61 & 1156.24 & 3.7 & 0.43 & $S$ \\
\hline $10 \mathrm{H}-6,18$ & 87.48 & 1165.76 & 3.44 & 0.08 & $S$ \\
\hline $11 \mathrm{H}-2,116$ & 91.96 & 1214.79 & 3.69 & -0.77 & $\mathrm{M}$ \\
\hline $11 \mathrm{H}-4,64$ & 94.44 & 1241.93 & 4.31 & -0.09 & $S$ \\
\hline $11 \mathrm{H}-6,20$ & 97 & 1269.95 & 4.06 & -0.48 & $M$ \\
\hline $11 \mathrm{H}-\mathrm{CC}, 0$ & 98.67 & 1288.22 & 4.52 & -1.47 & $M$ \\
\hline $12 \mathrm{H}-1,118$ & 99.98 & 1308.03 & 4.33 & -1.46 & $M$ \\
\hline $12 \mathrm{H}-2,80$ & 101.1 & 1320.29 & 3.81 & -0.08 & $M$ \\
\hline $12 \mathrm{H}-3,13$ & 101.93 & 1329.37 & 3.75 & -0.1 & $S$ \\
\hline $12 \mathrm{H}-4,85$ & 104.15 & 1353.67 & 3.78 & 0.06 & $\mathrm{M}$ \\
\hline $12 \mathrm{H}-7,13$ & 107.93 & 1395.04 & 3.59 & 0.11 & $S$ \\
\hline $12 \mathrm{H}-\mathrm{CC}, 11$ & 108.16 & 1398.76 & 3.61 & 0.27 & $S$ \\
\hline $13 \mathrm{H}-1,58$ & 108.88 & 1405.43 & 3.86 & -0.01 & $S$ \\
\hline $13 \mathrm{H}-2,24$ & 110.04 & 1418.13 & 2.95 & 0.49 & $S$ \\
\hline $13 \mathrm{H}-3,125$ & 112.55 & 1445.59 & 3.47 & -0.28 & $M$ \\
\hline $14 \mathrm{X}, \mathrm{CC}, 0$ & 115.9 & 1541.9 & 3.36 & 0.23 & $S$ \\
\hline $18 \mathrm{H}-\mathrm{CC}, 30$ & 150.6 & 1861 & 3.76 & -7.62 & $M$ \\
\hline $19 \mathrm{H}-1,90$ & 151.6 & 1871.96 & 3.84 & -0.7 & $M$ \\
\hline
\end{tabular}

Note: $M=$ smaller samples analyzed by PRISM mass spectrometer, $S=$ larger samples analyzed by SIRA mass spectrometer. 
P.F. BARKER ET AL.

DATA REPORT: OXYGEN AND CARBON ISOTOPE MEASUREMENTS

Table T2. Oxygen and carbon isotopic measurements on N. pachyderma (s), Hole 1101A.

\begin{tabular}{|c|c|c|c|c|c|}
\hline $\begin{array}{l}\text { Core, section, } \\
\text { interval }(\mathrm{cm})\end{array}$ & $\begin{array}{l}\text { Depth } \\
\text { (mbsf) }\end{array}$ & $\begin{array}{l}\text { Age } \\
(\mathrm{ka})\end{array}$ & $\begin{array}{l}\delta^{18} \mathrm{O} \\
(\% o)\end{array}$ & $\begin{array}{l}\delta^{13} \mathrm{C} \\
(\% o)\end{array}$ & Analysis \\
\hline \multicolumn{6}{|l|}{ 178-1101A- } \\
\hline $1 \mathrm{H}-3,40$ & 3.4 & 48.34 & 4.79 & 0.29 & $\mathrm{M}$ \\
\hline $1 \mathrm{H}-6,60$ & 8.1 & 114.71 & 4.5 & 0.62 & $S$ \\
\hline $1 \mathrm{H}-\mathrm{CC}, 28$ & 8.68 & 121.79 & 4.63 & 0.65 & $S$ \\
\hline $2 \mathrm{H}-\mathrm{CC}, 28$ & 18.48 & 260.7 & 4.43 & 0.27 & $\mathrm{~S}$ \\
\hline $3 \mathrm{H}-4,19$ & 22.89 & 325.47 & 4.57 & 0.11 & $\mathrm{M}$ \\
\hline $3 \mathrm{H}-\mathrm{CC}, 16$ & 27.86 & 394.1 & 4.58 & 0.17 & $S$ \\
\hline $4 \mathrm{H}-5,90$ & 34.6 & 489.98 & 4.37 & -0.05 & $S$ \\
\hline $4 \mathrm{H}-7,76$ & 37.46 & 530.48 & 3.73 & 0.39 & $S$ \\
\hline $5 \mathrm{H}-\mathrm{CC}, 13$ & 37.83 & 535.3 & 4.2 & 0.28 & $S$ \\
\hline $6 \mathrm{H}-2,40$ & 40.1 & 567.87 & 4.92 & -0.14 & $S$ \\
\hline $6 \mathrm{H}-5,40$ & 44.6 & 634.15 & 4.57 & -0.19 & $S$ \\
\hline $6 \mathrm{H}-\mathrm{CC}, 19$ & 48.1 & 683.92 & 4.42 & -0.46 & $\mathrm{M}$ \\
\hline $7 \mathrm{H}-5,130$ & 55 & 782.03 & 3.9 & 0.24 & $S$ \\
\hline $7 \mathrm{H}-6,110$ & 56.3 & 798.68 & 4.64 & -0.19 & $S$ \\
\hline $7 \mathrm{H}-7,14$ & 56.84 & 805.62 & 3.01 & -0.62 & $S$ \\
\hline $7 \mathrm{H}-\mathrm{CC}, 8$ & 57.4 & 812.82 & 4.1 & 0.28 & $M$ \\
\hline $8 \mathrm{H}-3,13$ & 60.33 & 850.47 & 4.29 & -0.03 & $\mathrm{M}$ \\
\hline $8 \mathrm{H}-4,94$ & 62.64 & 880.16 & 4.21 & -0.24 & $M$ \\
\hline $9 \mathrm{H}-2,71$ & 68.91 & 960.74 & 3.42 & 0.12 & $S$ \\
\hline $9 \mathrm{H}-4,93$ & 72.13 & 1005.03 & 3.85 & -0.26 & $S$ \\
\hline $9 \mathrm{H}-5,65$ & 73.35 & 1024.75 & 3.74 & -1.06 & $M$ \\
\hline $9 \mathrm{H}-\mathrm{CC}, 6$ & 75.96 & 1066.89 & 3.79 & -0.08 & $S$ \\
\hline $10 \mathrm{H}-1,24$ & 76.44 & 1074.54 & 3.91 & -0.02 & $S$ \\
\hline $10 \mathrm{H}-3,107$ & 80.27 & 1134.46 & 3.77 & -1.13 & $S$ \\
\hline $10 \mathrm{H}-4,27$ & 80.97 & 1145.41 & 3.99 & 0.18 & $S$ \\
\hline $10 \mathrm{H}-6,89$ & 84.59 & 1202.05 & 4.23 & -0.29 & $S$ \\
\hline $10 \mathrm{H}-\mathrm{CC}, 9$ & 84.99 & 1207.3 & 3.78 & -0.15 & $S$ \\
\hline $11 \mathrm{H}-4,93$ & 91.13 & 1304.38 & 3.94 & -0.2 & $S$ \\
\hline $11 \mathrm{H}-5,135$ & 93.05 & 1334.42 & 4.11 & -0.12 & $S$ \\
\hline $11 \mathrm{H}-6,53$ & 93.73 & 1345.06 & 3.88 & -0.92 & $S$ \\
\hline $11 \mathrm{H}-\mathrm{CC}, 0$ & 94.2 & 1352.41 & 3.96 & -0.76 & $S$ \\
\hline $12 \mathrm{H}-1,89$ & 96.09 & 1381.98 & 3.59 & -1.72 & $S$ \\
\hline $12 \mathrm{H}-2,50$ & 97.2 & 1399.35 & 3.61 & -5.33 & $S$ \\
\hline $13 \mathrm{H}-3,26$ & 107.96 & 1567.7 & 3.51 & 0.07 & $S$ \\
\hline $13 \mathrm{H}-4,60$ & 109.8 & 1596.49 & 4.43 & 0.15 & $M$ \\
\hline $13 \mathrm{H}-5,29$ & 110.99 & 1615.11 & 3.74 & -11.19 & $S$ \\
\hline $13 \mathrm{H}-7,69$ & 123.8 & 1854 & 3.55 & -2.21 & $M$ \\
\hline $16 \mathrm{H}-1,80$ & 134 & 2062.41 & 2.88 & -1.34 & $M$ \\
\hline
\end{tabular}

Note: $\mathrm{M}=$ smaller samples analyzed by PRISM mass spectrometer, $S=$ larger samples analyzed by SIRA mass spectrometer. 